\title{
Similarities and differences between "traditional" and "nontraditional" college students in selected personality characteristics
}

\author{
LORETTA MCGREGOR \\ Southern Arkansas University, Magnolia, Arkansas \\ HOLLY R. MILLER, MECHELLE A. MAYLEBEN, VICTORIA L. BUZZANGA, \\ and STEPHEN F. DAVIS \\ Emporia State University, Emporia, Kansas \\ and \\ ANGELA H. BECKER \\ Texas A\&M University, College Station, Texas
}

\begin{abstract}
In recent years, many colleges and universities in the United States have suffered a decline in the enrollment of students of "traditional" age (17-24 years). A new group of students has assumed many of the places once held by many "traditional" students; these newcomers, over the age of 25 years, have been labeled "nontraditional." For the present study, the short form of the Taylor Manifest Anxiety Scale, the Texas Social Behavior Inventory, and the Self-Perception Profile were used to evaluate selected personality characteristics of both "traditional" and "nontraditional" undergraduates. The results indicated that only minimal differences exist between these two groups. However, significant gender effects, notably in the areas of manifest anxiety and self-esteem, were obtained.
\end{abstract}

For numerous reasons, many adults are deciding to return to, or begin, a college career (Sewall, 1984, 1986). Because they are older than most "traditional" students, who fall into the 17- to 24-year-old bracket (Long, 1980), these students have come to be known as "nontraditional." Reports showing a concomitant decrease in the enrollment of "traditional" students and increase in the enrollment of "nontraditional" students underscore the impact and potential importance of this student group (Hruby, 1985).

Although the "nontraditional" student has only recently begun to receive the attention of much research, this is not the first time that older individuals have attended college (see Cross, 1982; Houle, 1961; Kasworm, 1980). The introduction of the G.I. Bill in the 1940s, for example, helped produce an increase in the number of older men who enrolled as undergraduate students. Nevertheless, prior to this period, most universities' enrollments of "adult" students were disproportionately low, except in correspondence courses, night courses, extension courses, special classes for "adults," or graduate courses (Kasworm, 1980). The number of female students also

\footnotetext{
Portions of this paper were presented at the 1990 meeting of the Southern Society for Philosophy and Psychology, Louisville, KY. Requests for reprints should be addressed to Stephen F. Davis, Department of Psychology, Emporia State University, Emporia, KS 66801.
}

increased as women began to enter traditionally maledominated career areas (Kasworm, 1980).

The influence of the new, diverse population of nontraditional students has prompted several new questions for teachers and researchers. For example, Astin (1984) stated that "the older student, in my judgment, is the most poorly understood of all the so-called 'new' student groups"' (p. 8). Puryear (1988) suggested that colleges must begin to focus on the unique needs of "nontraditional" students. Kasworm (1982) has suggested that these students differ appreciably from their "traditional" counterparts in their psychological, socio-emotional, and behavioral needs. Unlike the majority of "traditionally" aged students, "nontraditional" students must cope with additional barriers outside the classroom. Many "nontraditional" students have a spouse, children, and hold a full-time job in addition to going to school. The role of student is usually coupled with one or more of these additional roles. Often, these disparate roles compete with each other for priority within the "nontraditional" students' lives (Young, 1984).

"Nontraditional" women may encounter even greater difficulties when attending college. Rogers (1981) stated that "nontraditional" women usually face such problems as "(1) an undue amount of self-inflicted pressure ... (2) test anxiety, and (3) a lack of emotional/and or physical support from other family members" (pp. 1-2). In addition to the external problems that many "nontraditional" students must face, other researchers suggest that 
the unsharpened academic abilities of "nontraditional" students also may place additional pressures on them (Prager, 1983; Sewall, 1984).

Although data reflecting the influence of such variables as family and occupational obligations, lack of support, and unsharpened academic skills have begun to appear in the literature, little is known about personality differences that may exist between "traditional" and "nontraditional" students. In one study (Sadowski, Loftus-Vergari, \& Davis, 1978), the issue of control was examined with respect to both "traditional" and "nontraditional" students. The results of this study indicated that the "nontraditional" males saw "their environment as more predictable and themselves as being more in control of their actions than did younger males"' (p. 618). This finding was not obtained when "traditional" and "nontraditional" females were compared. The present study was designed to yield additional, complementary data. Through the administration of appropriate instruments, measurements of self-esteem, manifest anxiety, and the self-perception of 13 additional personality domains were recorded.

\section{METHOD}

\section{Subjects}

The subjects were 286 volunteers from introductory psychology classes at a midwestern regional, state university with an enrollment of nearly 6,000 students. Nontraditional students, 25 years old or older, represent $23 \%$ of the student body within the university's total population. The "nontraditional" group was composed of 18 men and 34 women, while the "traditional" group consisted of 78 men and 156 women. The average age for the traditional students was 18.99 years, while the average age for the nontraditional students was 32.95 years.

\section{Testing Instruments}

A self-administering questionnaire booklet, which consisted of a demographic sheet requesting gender and age, the Texas Social Behavior Inventory - Form A (TSBI) (Helmreich \& Stapp, 1974), the unidimension short form of the Taylor Manifest Anxiety Scale (TMAS) (Hicks, Ostle, \& Pellegrini, 1980), and the Self-Perception Profile for College Students (SPP) (Neeman \& Harter, 1986), was prepared. The TSBI, which consists of 16 items pertaining to one's confidence and/or competence in social situations, is designed to measure self-esteem. Each TSBI item is scored on a Likert scale ranging from 0 to 4 . Therefore, a maximum self-esteem score of 64 is possible. The TMAS is a 20 -item true-false instrument designed to measure general anxiety.

The SPP provides a self-perception score in the following 12 selfconcept domains: creativity, intellectual ability, scholastic competence, job competence, athletic competence, appearance, romantic relationships, social acceptance, close friendships, parent relationships, humor, and morality. Additionally, the SPP yields a global self-worth score.

\section{Procedure}

Test administration took place during a regularly scheduled class session. Each student was given an informed consent form. General instructions concerning confidentiality rights were presented by the experimenter. Students who were willing to participate signed the form and returned it to the experimenter. Those students who were unwilling to participate were thanked for their time and dismissed.

After all consent forms had been returned, each subject was given a questionnaire booklet and instructed to read and follow the instructions that appeared on the first page of each questionnaire. The questionnaire booklets were collected when all subjects had finished. The entire testing procedure took approximately $50 \mathrm{~min}$.

\section{RESULTS}

A series of $2 \times 2$ analyses of variance with gender (male/female) and type of student (traditional/nontraditional) as factors were employed to analyze these data. Analysis of the TMAS scores indicated that women $(M=$ 9.11) had significantly higher $[F(1,282)=3.76, p<.05]$ manifest anxiety than did men $(M=7.81)$. Analysis of the TSBI scores indicated that men $(M=42.20)$ had significantly higher $[F(1,282)=4.66, p=.029]$ self-esteem than did the women $(M=39.74)$.

Analysis of the SPP scores yielded significant effects for the following scales:

Creativity (measure of individual's perception of own ability to be creative or inventive). The scores of the men $(M=11.63)$ were significantly higher $[F(1,282)=8.87$, $p=.003]$ than those of the women $(M=10.29)$.

Athletic competence (measure of individual's perception of own ability to perform in physical and sports activities). Gender $[F(1,282)=25.98, p<.001]$ and type of student $[F(1,282)=7.64, p=.006]$ were significant. Men $(M=11.92)$ scored higher than did women $(M=$ 9.09). Traditional students $(M=11.27)$ scored higher than did nontraditional students $(M=9.27)$.

Appearance (measure of how physically attractive individual feels he/she is and how happy with him/herself he/she is). The scores of the men $(M=11.39)$ were significantly higher $[F(1,282)=14.01, p<.01]$ than those of the women $(M=9.53)$.

Close friendships (measure of how lonely individual would feel if he/she had no close friend). There was a significant effect of type of student $[F(1,282)=8.08$, $p<.01]$ and a significant gender $\times$ type-of-student interaction $[F(1,282)=3.88, p<.05]$. The traditional students $(M=12.73)$ scored higher than did the nontraditional students $(M=11.26)$. However, Newman-Keuls tests revealed that the "traditional" women scored significantly higher $(p<.05)$ than did the three other groups. In turn, the "traditional" men scored significantly higher $(p<.05)$ than did the "nontraditional" women.

Parent relationships (measure of how well individual feels he/she gets along with his/her parents). The gender $\times$ type-of-student interaction was significant $[F(1,282)=$ $5.21, p=.021]$. Subsequent Newman-Keuls tests indicated that the scores of the nontraditional men were significantly higher $(p<.05)$ than those of the nontraditional women and traditional men. All other comparisons were nonsignificant.

Morality (measure of how moral individual feels his/her behavior is). Women $(M=12.94)$ scored significantly higher $[F(1,282)=5.61, p=.017]$ than did the men $(M=11.91)$.

\section{DISCUSSION}

The present data prompt several considerations and conclusions. First, the general finding that women had significantly higher manifest anxi- 
ety than men did corroborates previous reports (Tramill, Davis, Bremer, Dudeck, \& Elsbury, 1982; Tramill, Kleinhammer-Tramill, Davis, Parks, \& Alexander, 1984). Likewise, the significantly higher self-esteem scores recorded by the men in the present study are also in agreement with previously reported data (Davis, Bremer, Anderson, \& Tramill, 1983; Davis, Martin, Wilee, \& Voorhees, 1978).

Although the significant gender effects in the areas of manifest anxiety and self-esteem are informative, they should not overshadow the fact that differences between traditional and nontraditional students simply were not present in these areas. With minor exceptions, this lack of difference between "traditional" and "nontraditional" students was repeated in the results of the SPP. It is noteworthy that the type-of-student factor failed to achieve significance or enter into a significant interaction with gender for the following domains: job competence, scholastic competence, social acceptance, appearance, morality, intellectual ability, romantic relationships, humor, creativity, and global self-worth. Only in the cases of parent relationships, close friendships, and athletic competence did the type-of-student factor achieve significance or enter into a significant interaction with the gender factor.

With regard to the significant gender effects, the image of men that has been promoted by the media may explain the significantly higher appearance scores recorded by the men. Likewise, the significantly higher morality scores shown by the women and the significantly higher creativity and athletic competence scores shown by the men also may reflect societal expectations and pressures. The continuing need of the younger, traditional students to receive the support of a peer group may be appealed to in order to explain the fact that these students felt that they formed close friendships more readily.

With regard to the differences that were observed between the "traditional" and "nontraditional" students, the finding that the "traditional" women felt that they form close relationships more readily than did all other groups may reflect a stronger need for approval than that of the "traditional" men. The demands of a family and career may have reduced these needs in the case of the "nontraditional" students. It is not surprising that the younger, "traditional" students felt that they were more athletically competent. Finally, reasons for the elevated scores of the "nontraditional" men in the area of parent relationships are less obvious.

How does all of this relate to the college education of "nontraditional" students? The virtual lack of significant between-group differences suggests that "nontraditional" students may not have an abundance of unique emotional and psychological needs. Special programs, counseling sessions, and remedial laboratories designed just for "nontraditional" students may not be required. These sentiments echo those of Epstein (1987), who, after surveying "nontraditional" students, concluded that "the adult learner is really not so different from younger learners in relation to factors motivating individuals to become college students." Because many of these "nontraditional" students must support themselves and a family, what does seem to be more important is the appropriate scheduling of classes and the offering of current, viable degree programs.

\section{REFERENCES}

Astin, A. (1984). A look at pluralism in the contemporary student population. National Association of Student Personnel Administrators Journal, 21, 3-11.

Cross, K. P. (1982). Older students and higher education. Washington, DC: National Council on Aging.

Davis, S. F., Bremer, S. A., Anderson, B. J., \& Tramill, J. L.
(1983). The interrelationships of ego strength, self-esteem, death anxiety, and gender in undergraduate college students. Journal of General Psychology, 108, 55-59.

Davis, S. F., Martin, D. A., Wilee, C. T., \& Voorhees, J. W. (1978). Relationship of fear of death and level of self-esteem in college students. Psychological Reports, 42, 419-422.

Epstein, H. V. (1987). College students come of age. Paper presented at the annual meeting of the American Society on Aging.

Helmreich, R., \& StapP, J. (1974). Short forms of the Texas Social Behavior Inventory (TSBI), an objective measure of self-esteem. Bulletin of the Psychonomic Society, 4, 473-475.

Hicks, R. A., Ostle, J. R., \& Pellegrini, R. J. (1980). A unidimensional short form of the TMAS. Bulletin of the Psychonomic Society, 16, 447-448.

Houle, C. O. (1961). The inquiring mind. Madison, WI: University of Wisconsin Press.

HRUBY, N. J. (1985). MIA: The nontraditional student. Academe, 71, 26-27.

KASWORM, C. (1982). Lifespan differences between student groupings. Journal of College Student Personnel, 23, 425-428.

KASWORM, C. E. (1980). The older student as an undergraduate student. Adult Education, 31, 30-47.

LoNG, H. B. (1980). Characteristics of senior citizens' educational tuition waiver in twenty-one states: A follow-up study. Educational Gerontology, 5, 139-149.

NEEMAN, J., \& HARTER, S. (1986). Manual for the self-perception profile for college students. Denver, CO: University of Denver.

Prager, K. J. (1983). Educational aspirations and self-esteem in returning and traditional community college students. Journal of College Student Personnel, 24, 144-147.

Puryear, A. (1988). Understanding the needs of adult students. Community Services Catalyst, 18, 30-47.

RoGERs, G. W., JR. (1981). Nontraditional, female, commuter students: Coping with college. (ERIC Document Reproduction Service No. 207 450)

Sadowski, C. J., Loftus-Vergari, M. C., \& Davis, S. F. (1978). Locus of control among students of traditional and nontraditional college age. Psychological Reports, 43, 618.

SEWALL, T. J. (Ed.) (1984). Nontraditionals in a traditional setting: Why older adults return to college. (ERIC Document Reproduction Service No. 267 257)

SEWALL, T. J. (1986). A study of adult undergraduates: What causes them to seek a degree. Journal of College Student Personnel, 25, 309-314.

Tramill, J. L., Davis, S. F., Bremer, S., Dudeck, M. M., \& ElsBURY, D. L. (1982). A proposed relationship between the unidimensional short form of the TMAS and the DAS: The effects of embedding vs. separate administration. Bulletin of the Psychonomic Society, 19, 209-211.

Tramill, J. L., Kleinhammer-Tramill, P. J., Davis, S. F., Parks, C. S., \& AleXander, D. (1984). The relationship between the Type A behavior pattern, fear of death, and manifest anxiety. Bulletin of the Psychonomic Society, 22, 42-44.

Young, M. A. (Ed.) (1984). Institutional planning for non-traditional students at a rural state college. (ERIC Document Reproduction Service No. 261 562)

(Manuscript received August 22, 1990.) 